\title{
THE ISSUE OF READINESS FOR PROFESSIONAL ACTIVITY: THEORETICAL ASPECTS
}

\author{
Oksana Havryshkiv \\ Lecturer at the Department of Foreign Languages and Military Translation, \\ Hetman Petro Sahaidachny National Army Academy, Ukraine \\ e-mail: oksana589@ukr.net,orcid.org/0000-0002-1898-9684
}

\section{Summary}

The article presents an analysis of theoretical psychological and pedagogical research by domestic and foreign scientists devoted to the issue of readiness for professional activity; highlights works in which the types (moral, psychological, command, authoritative, creative, communicative) and varieties (preliminary, premature, potential, direct, instantaneous, situational) of readiness are singled out. General concepts of the interpretation of readiness for professional activity in the psychological, pedagogical and military spheres are characterized. A distinction has been made between the various definitions relating to the training and readiness of future servicemen. The general algorithm of professional development of future officers is highlighted and the levels of readiness for professional activity are singled out: hyberbolized, optimal, reduced and unpreparedness as the lowest level. The nature and structure of readiness for professional activity are defined and theoretically substantiated.

Keywords: development, quality, pedagogical activity, formation for professional activity, psychological and pedagogical problem, components.

\section{DOI: https://doi.org/10.23856/3858}

\section{Introduction}

Society needs highly qualified, competitive specialists who are characterized by competence, business perseverance, ability to take risks and make independent decisions, that is, persons who possess both the professional and personal skills required for work. In order to be a successful specialist in any field, such qualities as search activity, social responsibility, organization, practical orientation and strong-willed perseverance are necessary.The issue of readiness for professional activity is an important psychological and pedagogical problem that requires detailed theoretical analysis and practical research.

Higher education is an important factor for a person's professional development. Therefore, the quality of higher education directly affects the success of both the individual and the positive development of society as a whole. Every novice specialist must have fundamental knowledge, professional skills as well as experience in creative and research activities to solve new problems. Comprehensive education is increasingly seen as a necessary condition for achieving the desired standard of living and as one of the factors for the progress of the economy and society as a whole.

Education today is undergoing significant changes associated with the adoption of new government standards. Modern technical innovation, computerization and the expansion of communication channels and flows in the spheres of production, education and science are accompanied by a change in social needs of the level and quality of professionalism of modern workers. If previously acquired knowledge in a higher education institution was enough for 20-25 years of successful practical professional activity, today the optimal period of their 
effectiveness is a maximum of 5-7 years, and almost two times less in the fields at the cutting edge of scientific and technological progress. This emphasizes the need for new training methodologies (Khomenko, 2017).

Job seekers in the modern labor market are required to be able to transfer their knowledge across various spheres of life in a changing socio-economic situation and ensure the constant updating of their skills in addition to having high qualifications in their main specialty. The instability inherent in the current economic situation makes particularly stringent demands on the professional in terms of maintaining his competitiveness, ensured primarily by a high level of professional competence, which today cannot be achieved without appropriate training.

The purpose of the article is to carry out a theoretical analysis of the problem of formation of readiness for professional activity of future specialists, to characterize the main approaches for understanding the concept of "readiness" and to highlight its structural components.

\section{Categorisation of readiness as a psychological and pedagogical problem}

The problem of readiness is studied by scientists in various fields, including philosophers, psychologists, sociologists and educators. For this study, it is expedient to consider the category of readiness in its psychological and pedagogical aspects.

In the Merriam Webster Dictionary, readiness is defined as a state of preparation.

In psychological literature there are several definitions of the concept of "readiness", which embody certain differences in its interpretation:

1. Readiness is the actively-effective state of the person, being set on a certain behavior, mobilization of strength to perform the task; readiness for action requires knowledge, skills, perseverance and determination to perform these actions (Pobirchenko, 2007).

2. Readiness is a state of personality that allows one to successfully enter the professional environment and develop professionally (Education ua, 2005).

3. Readiness is a set of factors that characterize different levels and aspects of readiness; depending on the conditions of activity, one or the other side of readiness may be dominant (Buiniak, 2019).

As a thorough analysis of the scientific psychological literature has shown, the diversity of approaches of scientists to the definition of "psychological readiness" is explained, in our opinion, by the ambiguity and complexity of this phenomenon. In particular, psychological readiness is interpreted as:

- a mental state, which is characterized by such features as: optimal arousal, high stability of nervous processes, persistence in achieving goals, self-confidence, self-regulation and self-esteem; the essence of psychological readiness is the ability of the subject to make decisions in a given situation in accordance with existing motives and objectives; in the psychological combination of activity and state; the ability to control the situation and regulate the results of each action, which is carried out purposefully (Puni, 1973);

- a temporary phenomenon capable of readiness and efficiency (Levitov, 1963);

- changes in the human psyche that occur in connection with the peculiarities of the activity and are necessary to adapt to it (Genov, 1982);

- a certain type of functioning and mental state that ensures the speedy work (Molyako, Nersesyan, 1985).

K. Platonov singles out psychological readiness for work as a subjective state of the individual, which reflects his readiness for activity. Platonov proposes the following definition: 
"readiness is the subjective state of a person who considers himself capable and prepared to perform a certain professional activity and who seeks to perform it" (Platonov, 1984: 25).

It should be noted that in the scientific psychological literature, the terms "readiness" and "preparedness" are often used as synonyms. A. Petrovsky and A. Markova see differences in them: readiness, in their opinion, pertains to a characteristic of the motivational sphere, and preparedness pertains to a characteristic of professionalism (Markova, 1996).

From the theoretical point of view, scientists distinguish general (long-term) and situational (short-term) readiness (Hornostai, Diachenko, Kandybovych, Slastonin).

Thus, according to Hornostai, the concept of professional readiness should be understood as the general readiness of a person for professional activity (both psychological and physical), which can be both long-term (professional training) and short-term.

General readiness, according to the researcher, is a stable system of professionally important qualities of a person (attentiveness, positive attitude to the profession, etc.), his experience, knowledge, skills necessary for successful activity in different circumstances. It reveals the potential for performing the task in the best way. However, it depends on readiness at a certain moment, that is, on the state before the start of the task - a mood, that reflects the conditions and requirements of the situation.

Situational readiness is seen as the actualization of long-term readiness, which increases its effectiveness. Both forms of readiness are united and interconnected. The emergence of short-term readiness depends on long-term readiness, in turn, long-term readiness determines the situational ability to think, memory, skills, knowledge and the ability as a whole (Hornostai, 1985).

M. Levitov, considering readiness to work, points to the presence of a special mental state, which he calls a temporary, pre-start state. Levitov distinguishes three types of pre-start state of readiness for work:

-a normal (or neutral) state is manifested before work to which the person is accustomed and does not foresee it entailing additional requirements;

-a state of heightened readiness is observed when a person feels enthusiasm for and interest in a new activity;

-a state of low readiness is manifested in the case of predominance of negative emotions and mental states (lack of interest in work, fear, indecision, self-doubt) before the start of the working day (Levitov, 1964).

According to Bykova, readiness for professional activity can be reduced to the presence of professionally important qualities and personality traits. She formulates the concept of "readiness" for professional activity as a psychological and pedagogical taxonomy of a necessary and sufficient set of professionally important qualities and personality traits. In her opinion, readiness for professional activity includes moral and psychological, commanding, authoritative, creative and communicative aspects. Command readiness is natural leadership talent, authority, instant understanding of the social significance of the combat mission, responsibility, intuition, high creative activity, rationality in their management, courage, capacity for non-standard solutions, determination, endurance and self-control, confidence, persuasiveness, argumentativeness efficiency of decision-making and readiness for danger. Authoritative readiness contains motivational, regulatory, transformative, informational-cognitive, regenerative, educational-disciplinary, moral-ethical, authoritarian-prestigious, official, managerial, leadership and charismatic components. Creative readiness encompasses idea generation, heuristic creative activity, professional ambition, divergence, search, flexibility of mind, scientific sociability, depth of knowledge, lexical capacity and high scientific authority. Communicative readiness 
involves psychological compatibility, active life position, commitment to duty, common views with the team, professional friendship, mutual assistance, brotherhood, respect for colleagues, the rules of coexistence, good public speaking skills and the ability to use professional language in professional speech situations (Bykova, 2016).

There are different approaches for the interpretation of readiness in its pedagogical aspect. First of all, it should be noted that scientists look at the definition of the concept of "readiness for teaching" from the point of view of the functional or personal approaches, but most of them adhere to the latter, believing that psychological readiness for teaching is an outcome of completed learning (Linenko, 1995).

In pedagogical research, readiness is interpreted as a holistic comprehensive manifestation of personality, which has the ability to contribute to the effective implementation of the person's activities and the use of their professional functions. It is acquired in the process of psychological, moral, professional and physical training, which is the result of comprehensive development of the individual, taking into account the requirements of professional activity.

Analysis of the meaning of the concept of "readiness" shows that almost all scientists understand it as a readiness for a certain action, with a common emphasis in all definitions being the subject's desire to carry out it in the best way.

The basis of most scientists on the problem of readiness of teachers for professional activity are the works of F. Honobolin, V. Krutetsky, N. Kuzmina, etc., which highlight the features of professional activity of teachers as well as reveal the role of professional motivation and pedagogical abilities (Kuzmina, 1993).

According to Kremen, the professionally important qualities of European teachers include a high level of self-control, sociability, willingness to cooperate, self-confidence and emotional balance.

According to Kremen, it is the individual characteristics of the teacher that provide the fundamental basis of his professional individuality, and personal-subjective provide the essential basis. The teacher as an individual has natural abilities such as general health, features of temperament, cognitive processes (the type of memory that prevails, attention, imagination, logic of thinking) and special abilities, including pedagogical ones. The teacher's individuality is revealed in the fact that he has his own features and system of relations with the outside world (Kremen, 2005).

Buiniak draws attention to the work of Krutetskyi, where he considers readiness for pedagogical activity as a set of pedagogical abilities necessary for its successful implementation. These include:

- didactic abilities - the teacher's ability to teach the course contents, stimulate students' thinking and their interest in the subject;

- academic abilities- the teacher's general awareness and his deep knowledge in this field of science, which he teaches;

- perceptive abilities - the ability to perceive the students' inner world and to understand their moods and mental states;

- speaking abilities - the ability to clearly express their thoughts and use non-verbal means of communication (Buiniak, 2019).

Piekhota highlights such personal characteristics as motivation and direction of professional activity, empathy, tolerance, psychological literacy and competence, the level of development of communicative and organizational skills, identification of accentuations in teaching and much more as significant teacher qualities. Summing this up, the author includes the following components in the structure of professional readiness of a teacher: 
1) humanistic worldview and humanistic knowledge, the ability to form interactions with another person in terms of empathy, tolerance and unconditional acceptance;

2) psychological state and level of education;

3 ) the ability and need for self-analysis of their own qualities and actions as an individual;

4) the ability and need for personal and professional self-improvement;

5) high creative potential

6) the ability to resolve personal and professional contradictions in a humanistic way, without violating the individual logic of action and the general development of the student;

7) the ability to compile and implement individual personal and professional development programs for a specific development stage (Piekhota, 2011).

Kuzmina offers her model of readiness for pedagogical activity, according to which the successful solution of various pedagogical tasks are aided by:

1) a set of knowledge (socio-political and cultural knowledge; knowledge of the subject, means of pedagogical communication, the characteristics of students, knowledge of the advantages and disadvantages of own actions;

2) incentives and motives;

3) the directedness of the teacher's personality;

4) pedagogical skills;

5) professionally significant qualities of the teacher as a person (Kuzmina, 1980).

According to Kuzmina, pedagogical mastery is the highest level of pedagogical activity (where there are qualitative indicators of the result), as a manifestation of creative activity of the teacher's personality (Kuzmina, 1989).

Noteworthy is the definition of readiness proposed by Derkach, who states that the readiness of graduates for professional activities should be studied through the activities of the individual, when the student forges their own capabilities and prospects, expands their systematic professional skills, learns and carves out new, simple ways to solve professional problems in the course of professional training (Derkach, 2003).

Derkach also singles out the following structural components of a teacher's readiness for professional activity:

- motivational - a positive attitude to the activity, the desire to engage in it;

- cognitive - the presence of necessary knowledge, skills and ideas;

- gnostic - mastering the means and methods of implementing various aspects of the activity;

- emotional-volitional - self-control and emotional stability;

- evaluational - self-assessment of professional preparedness (Derkach, 1999).

Moroz, studying readiness, drew attention to the work of Shakhov, who considers readiness a professionally important quality in a teacher, which affects the success of professional adaptation and identifies the following components: motivational, which implies a positive attitude to the profession, interest in it and other stable professional motives; orientational, which combines knowledge and ideas about the specifics and conditions of professional activity, the requirements for their personality; operational, which determines the mastery of professional methods and techniques, necessary knowledge skills, analytical skills, abilities, synthesis, comparison, generalization: volitional, including self-control, the ability to manage actions during performance of duties; evaluative, which involves self-assessment of their professional training and compliance of the process of solving professional problems with optimal working procedures (Shakhov, 2007).

The readiness of the future teacher for professional self-development is considered by researchers (A. Bystryukova, O. Piekhota, T. Strytievych., T. Tykhonova and P. Kharchenko) 
mainly as an integrative personality trait, represented by a set of personal, professional qualities and states that allow future teachers to successfully carry out professional activity and to self-improve.

\section{Understanding and types of professional readiness, its structure}

Professional readiness of a specialist is a complex, multilevel, multifaceted systemic mental construct, first of all a person's creation.

At the same time, professional readiness presupposes that the specialist has the appropriate level of physical health, the formation and development of physical qualities necessary for successful professional activity, and the presence of an appropriate level of physical culture. This is obvious, because any professional activity is associated with the consumption of not only mental but also physical energy.

It is expedient to discern between two interconnected varieties of professional readiness (Diachenko, Stoliarenko):

- preliminary, premature, potential readiness as a professional preparedness of the individual for the relevant activity. This readiness of the specialist includes: a system of fairly stable, static components, mental formations, knowledge, skills, professional abilities, professionally important qualities, values of the individual, his attitudes and preferences. In general, this encompasses a certain level of professionally required personality potential;

- direct, instantaneous, situational readiness as a state of appropriate mobilization, functional orientation of the psyche of the specialist to solve specific problems in appropriate circumstances and conditions. This aspect of professional readiness of the specialist is characterized by high dynamism, mobility and dependence on situational circumstances, the state of mental and physical health of the specialist, the moral and psychological atmosphere in the team and the social environment, etc.

Based on the theoretical analysis, we identify such components of professional readiness as psychological and communicative readiness.

The leading and most difficult aspect of professional readiness of a specialist is psychological, that is the professional readiness of the psyche of a specialist. This is the degree of preparation and adjustment of the psyche, the spiritual strength of the specialist and the solution of professional problems, the performance of their functional duties. following:

The main components of professional readiness of the psyche of a specialist are the

- indicative, intellectually cognitive. This component includes a certain level of professional development of the cognitive sphere of the specialist's personality, professional perception, thinking, imagination, memory, attention. All in all, this is the intellectual and cognitive readiness of the specialist;

- motivating, determines the professional orientation of the individual. The basic basis of the motivational readiness of a specialist is the understanding of the meaning of one's profession, specialty, a positive attitude to it, the necessary level of self-esteem and aspirations in activity. In higher level education, motivational readiness for professional activity is expressed in the real motivational orientation of students on professional and personal development and self-development in the educational process;

- executive, which includes professional skills (a set of professionally important qualities, knowledge, skills, abilities, habits of professional behavior), the required level of 
professionally important abilities and willpower of the specialist, his ability to self-regulate behavior and activities, that is his operational readiness.

The core of the professional readiness of a specialist is the professional orientation of the individual and professional skill.

A special role in the professional readiness of a modern specialist is played by his communicative readiness. This readiness implies that the professional has a sufficient level of development of skills and abilities of constructive and effective contact with people, with the professional environment, professional communication with employees and managers, willingness to interact with colleagues and the ability to establish, maintain and develop such interaction.

Communicative readiness is possible only with a sufficient level of human speech culture and the ability to use words and language correctly. The speech culture of an individual is an important indicator of the level of development of his culture of thinking, and the professional speech culture of a specialist is an indicator of the development of his professional thinking. That is why the development of general and professional speech culture in the training of specialists is one of the integral conditions of their personal and professional development.

An important condition for the success of the specialist is his readiness and ability for professional and personal self-affirmation, his corresponding activity in this direction; the desire to most fully and comprehensively realize himself both in solving professional problems and in relationships with employees and colleagues. The success of such self-affirmation of the specialist largely depends on his desire and willingness to succeed and on a positive attitude.

\section{The issue of readiness of future officers}

In addition to the above-mentioned readiness in terms of psychology and pedagogy, an important place is occupied by the military training of future officers, today's cadets. Current events in Ukraine impose a number of new requirements on future officers. The main important scientific and practical task facing modern military education is to create a qualitatively new system of training of future servicemen, which is a set of special knowledge, skills and abilities that corresponds to the military specialty and professional experience (wars and military conflicts, including the anti-terrorist operation in Eastern Ukraine).

The training of future officers is one of the pressing problems of military education and can be seen as a way out of the problematic situation that has arisen due to contradictions between the need to ensure the quality of education and the impossibility to solve this problem using existing traditional approaches.

The main integrated criterion of a future officer is readiness for professional activity. Therefore, new trends in the development of professional training of future officers involve a focus on fundamentality, competence and versatility, which are prerequisites for successful future professional activity.

Military-professional training of future officers is considered to be the main determinant of the general orientation of the personality in its complex property. This includes a system of motivations, determines the activity of the subject and is a set of values, needs and motives that prompt a person to engage in a particular activity.

Analysis of the practice of training future officers from the experience of leading countries, participation in the anti-terrorist operation in Eastern Ukraine and the experience of modern combat operations has provided an opportunity to review the current training of future officers and introduce new, modern and progressive methods of training. 
The professional training of future officers is a complex dynamic process that directly depends on interrelated factors and relationships that are formed and manifested on the basis of the general regularities in the pedagogical process (Kuzmina, 1982).

The process of training a new generation of officers capable of clearly acting in crisis situations, performing official duties and managing subordinate personnel is becoming a top priority for the development of the Armed Forces of Ukraine. Progress in the education and training of future officers must take place after the dialectical extinction of the obsolete and the birth of the new, which requires filling the pedagogy of higher military schools with new content.

The process of formation of knowledge, skills and abilities can be divided into two phases:

Problem-subject: initial perception and comprehension of content and experience of further professional activity;

Value-regulatory: formation of managerial (team) skills and abilities of the future leader are formed, development of creative style, motives, value orientations, leadership qualities (Khoriev, 2000).

The general algorithm of professional development of future officers includes the following stages:

- constitutive-motivational: the formation of motivation for the future officer's further professional activity. There is a constant enrichment and accumulation of knowledge, skills and abilities;

- content-search: includes the organizational functions of pedagogical activity of future officers;

- adaptive-transformative: transition of the received theoretical knowledge into a practical plane, acquisition of professional experience and its practical application;

- system-generalizing: the process of generalization and systematization of acquired knowledge, skills and abilities, bringing them to the appropriate professional level;

- control-reflexive: conducting final control, assessment and self-assessment of acquired knowledge (Bryzhatyi Y.I., 2014).

One of the important places in the professional training of future officers is the founding and motivational stage. It actualizes their positive attitude to further professional activity, forms and develops external and internal motivation, determines the main types of professional competence that they acquire in the process of professional training. The main task at this stage is the objective self-assessment by officers of future professional activity and the ability to make decisions under unexpected conditions.

Future officers need fundamental knowledge of the history of the art of combat, experience of wars, conflicts and anti-terrorist operations to be able to creatively apply them to modern conditions. Classical theories of war should not be rejected or ignored but rather adapted to the present era, as they fundamentally remain valid.

An officer masters his specialty with maximum dedication, and is then responsible for the results of his work, while performing tasks like a professional, not stopping at what has already been achieved and striving to reach a new professional level.

Thus, professional training gradually changes into the readiness of the future officer to perform professional tasks. The transition from readiness is accompanied by a gradual transition to competence. From competence the officer moves to professionalism, the highest step in the process of professional development-professionalism (Vitchenko, 2014).

Kovalenko, studying readiness for activity, drew attention to the opinion of Boykov, where he argues that the readiness of the individual as part of a team acts as a potential opportunity and ability to achieve high results in work (Kovalenko, 1999). Boykov identified two 
interdependent systems of components of the psyche in the psychological structure of the soldier's readiness-these are dynamic and stable components.

In general, Boykov claims that the level of human readiness for activity is characterized by the quality of military-professional training, as well as the mobilization of spiritual and physical forces for future activities. However, he reduces the overall readiness for activity to psychological readiness, where he singles out the following levels: hyperbolized, optimal, reduced and unpreparedness as the lowest level.

The hyperbolized level is manifested when mental tension is at the individual's extreme limit. The level of readiness will change depending on how the tension increases: a complete disorganization of the psyche or a change to the optimal level of functioning if the warrior overcomes himself.

The optimal level of readiness has the characteristic features of confidence in success of the mission, armaments, like-minded people, commanders and oneself; the full mobilization of erudition and knowledge, experience and skill; speed, economy of mental processes; high efficiency of activity.

The low level of readiness can be caused both by an insufficient level of general preparation, and by inability to adjust oneself to the execution of the task ahead (excessive self-confidence in the outcome or uncertainty as to whether the event being prepared for will take place).

Unpreparedness is defined as a lack of perception of activity and as complete disorganization, confusion, shock or complete reluctance and inability to act in the expected event.

Koval draws attention to the views of Boyko that the psychological readiness of the officer to manage is a complex dynamic mental creation that expresses a set of intellectual, emotional, motivational, operational-managerial and volitional components of his psyche in their relationship with management tasks and external conditions and includes the interaction and synergies of motivational, emotional-volitional, orientational-mobilizational, cognitive-eveluative, operational-managerial and intellectual components (Koval, 2003).

Based on the above, we come to the conclusion that the educational process in higher military institutions takes place in a contradiction between the new ever-increasing requirements for the current level of training of future officers and insufficient traditional level of training, between the creative level of teaching and the reproductive nature of training, which can be solved by introducing new progressive learning technologies.

\section{Conclusions}

Summarizing the above, we can conclude that a stable, final definition of readiness for activity has not been formed yet. There are three main approaches to its assertion: 1) readiness is understood as a complex formation that includes cognitive, motivational, emotional and volitional components, as a set of knowledge, skills and abilities and professionally important personality traits that a specialist must have to succeed. 2) readiness is understood as a certain functional state that serves a successful activity, ensures its high quality; 3) readiness is understood as a complex personal construct, that includes professionally important personality traits, skills and psychological states.

Important in the formation of each professional is the process of forming professional readiness for activity. Therefore, a leading place is occupied by teachers and psychologists, who pay special attention to the problem of forming readiness for professional activity. H. Kravchuk says that it is formed in the process of mastering general and professional knowledge, developing the necessary skills and abilities and improving acquired and developed personality traits (Kravchuk, 2013). 
Thus, readiness for professional activity is considered to be a complex socio-pedagogical phenomenon, which includes a system of professional and pedagogical knowledge, skills and abilities, a set of individual psychological qualities of the individual, his beliefs and views. The readiness of future professionals for professional development depends on their professional motivation and individual self-expression. Therefore, Ukraine needs specialists who can work independently and creatively, generating innovations, fresh ideas and proposals, while demonstrating a willingness to successfully implement them in a competitive environment. Requirements on personal and professionally significant qualities of specialists, which reflect professional competence, ensure competitiveness in the labor market and promote professional self-realization and career growth are increasing.

\section{References}

Bryzhatyi, Y. (2014). Viiskovo-profesiina pidhotovka maibutnikh ofitseriv: vid hotovnosti do profesionalizmu [Military-professional training offuture officers: from readiness to professionalism]. Kyiv: Natsionalnyi universytet oborony Ukrainy. [in Ukrainian]

Buiniak, M. (2019). Formuvannia psykholohichnoi hotovnosti vchyteliv do inkliuzyvnoho navchannia ditei z osoblyvymy osvitnimy potrebamy [Formation of psychological readiness of teachers for inclusive education of children with special educational needs ]. Kamianets-Podilskyi: Natsionalnyi pedahohichnyi universytet imeni Drahomanova. [in Ukrainian]

Bykova, O. (2001). Formuvannia hotovnosti do profesiinoi diialnosti maibutnikh ofitseriv pozhezhnoi okhorony [Formation of readiness for professional activity of future fire officers]. Kyiv: Molodyi vchenyi. [in Ukrainian]

Chomenko, K. (2017). Formuvannia profesiinoi kompetentnosti maibutnikh likariv v universytetakh Polshchi (1990-2015) [Formation of professional competence of future doctors in Polish universities (1990-2015)]. Kyiv: Natsionalna akademiia pedahohichnykh nauk Ukrainy. [in Ukrainian]

Derkach, A. (2003). Akmeolohiia: puty dostyzhenyia vershyn proffesionalisma [Acmeology: ways to reach the top of professionalism]. Moscow: RAU. [in Russian]

Hornostai, P. (1998). Formuvannia psykholohichnoi hotovnosti starshoklasnykiv do pedahohichnoi diialnosti [Formation of psychological readiness of high school students for pedagogical activity]. Psykholohichni nauky. [in Ukrainiian]

Khoriev, I. (2000). Pedahohichni osnovy zabezpechennia efektyvnosti pidhotovky viiskovykh fakhivtsiv u vyshchykh zakladakh osvyti [Pedagogical bases of ensuring the effectiveness of training of military specialists in higher educational institutions]. Kyiv: VHI NAOU. [in Ukrainian]

Kovalenko, O. (1999). Teoretychni zasady profesiinoi pedahohichnoi pidhotovky maibutnikh inzheneriv-pedahohiv v kontekti pryiednannia Ukrainy do Bolonskoho protsesu [Theoretical principles of professional pedagogical training of future engineers-teachers in the context of Ukraine's accession to the Bologna process]. Monohrafia. Kharkiv: UIPA. [in Ukrainian] Koval, M. (2014). Teoretychni aspekty psykholohichnoi hotovnosti maibutnikh riatuvalnykiv do diialnosti $v$ ekstrymalnykh umovakh [Theoretical aspects of psychological readiness of future rescuers to work in extreme conditions]. Pedahohika ta psykholohiia profesiinoi osvity. [in Ukrainian]

Kuzmina, N. (1982). Metody systemnoho pedahohichnoho doslidzhennia [Methods of systematic pedagogical research]. Lviv: LHU. [in Ukrainian] 
Kremen, V., Ilin, V. (2005). Filosofiia: myslyteli, idei, kontseptsii [Philosophy: thinkers, ideas, concepts]. Kyiv: Knyha. [in Ukrainian]

Kravchuk, H. (2013). Formuvannia hotovnosti do vykorystannia innovatsiinykh tekhnolohii-vazhlyva skladova profesiinoi pidhotovky fakhivtsiv bankivskoi spravy [Formation of readiness to use innovative technologies as an important component of professional training of banking specialists.] Rehionalna ekonomika. [in Ukrainian]

Levitov, N. (1964). Pro psyhologycheskye sostoyanie cheloveka [About psychological state of the person] Moscow:Prosvita. [in Russian]

Linenko, A. (1995). Pedahohichna diialnist i hotovnist do nei. Monohrafiia. [Pedagogical activity and readiness for it]. Odesa: OKFA. [in Ukrainian]

Moliako, V. (2004). Psykholohiia tvorchosti-nova paradyhma doslidzhennia konstruktyvnoi diialnosti liudyny [Psychology of creativity is a new paradigm for the study of constructive human activity]. Praktychna psykholohiia ta sotsialna robota. [in Ukrainian]

Osvita UA, (2005). Slovnyk psykholoho-pedahohichnykh poniat ta terminiv [Dictionary of psychological and pedagogical concepts and terms]. Electronic resourse. Retrieved from https://osvita.ua/school/method/psychology/1270/. [in Ukrainian]

Platonov, K. (1984). Metodolohichni ta teoretychni problemy psykholohii pratsi [Methodological and theoretical problems of labor psychology]. Zhytomyr: Zhytomyr State University named after Ivan Franko. [in Ukrainian]

Pobirchenko, N. (2007). Psykholohichnyi slovnyk [Psychological dictionary]. Kyiv: Naukovui svit. [in Ukrainian]

Puni, A. (1973). Deiaki psykholohichni pytannia hotovnosti do zmahan u sporti. [Some psychological issues of readiness for competitions in sports] Fizkultura i sport. [in Ukrainian]

Vitchenko, A. (2014). Neperervnist pidhotovky viiskovykh pedahohiv: vid hotovnosti do profesionalizmu ta maisternosti [Continuity of training of military teachers: from readiness to professionalism]. Kyiv: NUOU. [in Ukrainian]

Webster 's Dictionary of English Usage, (1989). Merriam-Webster Inc., Publishers Springfield, Massachusetts. [in English] 